\title{
TOŻSAMOŚĆ A WIZERUNEK I REPUTACJA PRZEDSIECBIORSTWA NA PRZYKŁADZIE KONCERNU MONSANTO
}

\author{
EMILIA WĄSIKIEWICZ-FIRLEJ
}

Pojęcia tożsamości, wizerunku i reputacji stały się kluczowe w odniesieniu do komunikacji przedsiębiorstw i instytucji. W literaturze przedmiotu można zauważyć jednak pewne trudności $\mathrm{z}$ definiowaniem tych pojęć oraz liczne nieścisłości i niekonsekwencję $\mathrm{w}$ ich stosowaniu związane przede wszystkich $\mathrm{z}$ wyodrębnieniem zakresu znaczeniowego poszczególnych terminów. Celem niniejszego artykułu jest zatem przegląd poszczególnych definicji i opracowanie ram referencyjnych do analizy dyskursu korporacyjnego. Poruszona zostanie problematyka spójności tożsamości, wizerunku i reputacji przedsiębiorstwa jako podstawy do jego sprawnego funkcjonowania czy wręcz dalszej egzystencji. Kryzys integralności tych elementów przedstawiony zostanie na przykładzie koncernu Monsanto - jednej z najpotężniejszych i jednocześnie najbardziej znienawidzonych korporacji na świecie.

\section{Tożsamość, wizerunek, reputacja}

Wielu badaczy podkreśla niekonsekwentne czy wręcz błędne stosowanie kluczowych w komunikacji biznesowej i instytucjonalnej terminów tj. tożsamość, wizerunek i reputacja (Gilpin, 2010; Barnett, Jermier i Lafferty, 2006; Brown et al., 2006; Gotsi i Wilson, 2001). Pojęcia te używane są często zamiennie w wielu dziedzinach (Barnett et al., 2006). Liczne rozbieżności terminologiczne dają zatem podstawę do przeglądu literatury przedmiotu w celu uporządkowania definicji poszcze- 
gólnych pojęć. Wydaje się to istotne ze względu na znaczącą rolę, którą elementy te odgrywają w komunikowaniu się oraz public relations.

Problematyczne wydaje się szczególnie rozróżnienie pojęć tożsamości przedsiębiorstwa i jego wizerunku. W tym celu warto przyjrzeć się klasyfikacji zaproponowanej przez Brown et al. (2006) (patrz Tab. 1), która oprócz pojęcia „tożsamości” odnoszącego się do femenologicznego pytania „Kim jesteśmy jako organizacja?” wyróżnia jeszcze cztery pojęcia pozostające w gestii zainteresowań marketingu, public relations i komunikacji korporacyjnej. W klasyfikacji tej najistotniejszą kwestią pozostaje fakt, że ,pożądany wizerunek” (ang. intended image) przedsiębiorstwa nie zawsze jest zbieżny z jego ,antycypowanym” wizerunkiem (ang. construed image) czy też reputacją. Przykładowo, korporacja Unilever posiada szeroką ofertę produktów różnych marek (np. proszek do prania Persil czy lody Ben i Jerry's), których wizerunki wywołują określone skojarzenia. $Z$ tego względu nagła zmiana wizerunku na bardziej ekologiczny i wprowadzenie na rynek produktu przyjaznego środowisku (np. płynu do prania Persil) w celu wykazania się społeczną odpowiedzialnością może wywołać pewien sceptycyzm ze strony konsumentów. W takim wypadku występuje rozbieżność pomiędzy reputacją firmy a jej „pożądanym wizerunkiem”. W większości przypadków trudno jednak nakreślić wyraźne granice semantyczne pomiędzy terminami zaproponowanymi przez Brown et al. (2006) ze względu na ich podobieństwo (np. Firma Apple - lider w dziedzinie innowacji i dizajnu - oferuje produkty i marki zharmonizowane z jej tożsamością i reputacją (Kenny et al., 2011: 127).

Tabela 1. Rozróżnienie pomiędzy tożsamością, wizerunkiem, reputacją a marką

\begin{tabular}{|l|l|}
\hline \multicolumn{1}{|c|}{ Termin } & \multicolumn{1}{c|}{ Kluczowe pytanie } \\
\hline Tożsamość & Kim jesteśmy jako organizacja? \\
\hline Wizerunek pożądany & W jaki sposób organizacja chce być postrzegana przez innych? \\
\hline Wizerunek antycypowany & Co organizacja uważa, że inni myśla o niej? \\
\hline Reputacja & Co inni rzeczywiście myśla o organizacji? \\
\hline Marka & $\begin{array}{l}\text { Które atrybuty i wizerunki chcemy, aby inni kojarzyli z określonym pro- } \\
\text { duktem/usługą? }\end{array}$ \\
\hline
\end{tabular}

Źródło: opracowano na podst. Brown et al., 2006, cyt. w Kenny et al., 2011: 127

Rozbieżności pomiędzy pożądanym a rzeczywistym wizerunkiem przedsiębiorstwa ilustruje przypadek korporacji z Hong Kongu zakodowanej w badaniach Bhatia and Lung (2006) jako XXX. Pomimo projekcji wizerunku odnoszącej sukcesy i wydajnej organizacji w kontrolowanych przez firmę kanałach komunikacji, XXX postrzegana jest $w$ mediach $w$ sposób negatywny ze względu na słabe wyniki na rynku. Dla przykładu, firma ogłasza się ,jako globalny lider technologii telekomunikacyjnych" (2003 Interim Results), podczas gdy w mediach przedstawiana jest 
jako firma telekomunikacyjna pozostająca ,poza kręgiem zainteresowań inwestorów" (SCMP: Marzec 5, 2004; cyt. w: Bhatia and Lung, 2006: 268). Taka rozbieżność pomiędzy autoprezentacją a postrzeganiem firmy stwarza potencjalne ryzyko dla jej dalszego funkcjonowania ze względu na to, iż jej intersariusze (tj. inwestorzy, pracownicy, potencjalni pracownicy, konsumenci, itp.) uzależniają swoje decyzje dotyczące inwestycji, kariery czy też wyborów konsumenckich od reputacji firmy (Melewar, 2003: 195).

Liczni badacze podkreślają, że sukces danej organizacji zależy w dużej mierze od spójności wszystkich elementów jej tożsamości, wizerunku i reputacji (np. Balmer i Greyser, 2002; Fombrun i Rindova, 2000; Simoes, Dibb i Fisk, 2005). Brak takiej integracji niesie ze sobą negatywne skutki dla przyszłości firmy ze względu na obniżenie zaangażowania pracowników i zmniejszenie satysfakcji klientów (Cornelissen et al., 2007; Hatch i Schultz, 2000, 2001).

\section{Teoria wizerunku Stanisława Puppla}

Cenny wkład do teorii wizerunku został wniesiony przez Stanisława Puppla (2016), który postuluje powszechność wizerunku wszelkich bytów w biosferze. Innymi słowy, posiadanie i utrzymywanie wizerunku, zarówno na poziomie gatunkowym jak i indywidualnym, jest integralną częścią ,,dynamiki życia” towarzyszącej „wszelkiej kohabitacji biologicznej” (ibidem: 110). Wizerunek człowieka charakteryzuje dualność związana z jego biologicznym i kulturowym wymiarem. Ponadto wizerunek możemy rozpatrywać jako statyczny vs. dynamiczny. Aspekt statyczny wizerunku odnosi się do świadomości własnej tożsamości organizmu biologicznego lub tworu kulturowo-instytucjonalnego w relacji do ,innych cielesności współpracujących lub konkurujących ze sobą we wszechobejmującej przestrzeni i arenie życia" (ibidem: 111). W wymiarze statycznym wizerunek człowieka podlega dalszej kategoryzacji, wyszczególniającej: (a) świadomość posiadania określonego wizerunku wewnętrznego rozumianego jako immanentny obraz siebie oraz (b) „świadomość konieczności i umiejętności wywołania określonego wrażenia, które ów obraz wywołuje u innych użytkowników otwartej przestrzeni publicznej” (ibidem: 112).

Dynamiczność wizerunku jest z kolei rozumiana jako ciągłe zaangażowanie się danej cielesności w podejmowanie działań o charakterze interakcyjno-komunikacyjnym w celu wywołania określonego pożądanego wrażenia na odbiorcach (,,innych"). Sygnalizowanie to może mieć charakter zarówno uczciwy jak i nieuczciwy. Dynamiczny aspekt wizerunku można również interpretować jako „adaptacyjny potencjał retoryczny" realizowany w określonych porządkach komunikacyjnych (Puppel, 2016: 111) oraz przy zastosowaniu szerokiego wachlarza strategii w celu osiągnięcia określonych celów perswazyjnych. Strategie te mogą być z kolei zakwalifikowane do szerszej kategorii ,architektury wizerunku”, która przyjąć może za- 
równo formę monolityczną pozwalającą na zachowanie holistycznego wyglądu, jak i fragmentaryczną, rozproszoną, skoncentrowaną na ekspozycji wybranych elementów wizerunku (Puppel, 2016: 115).

Model zaproponowany przez Puppla można stosunkowo łatwo zaaplikować do wizerunku przedsiębiorstwa. Zawiera on bowiem element auto-prezentacji danej organizacji, która w przypadku korporacji obejmuje również deklarację misji określającej podstawowe elementy tożsamości przedsiębiorstwa, które zawierają się w pytaniu „Kim jesteśmy i czym się zajmujemy”. Statyczny i dynamiczny wymiar wizerunku określony przez Puppla (2016: 111) w dużej mierze odpowiada deklarowanemu i rzeczywistemu wizerunkowi, co z kolei powinno znaleźć odzwierciedlenie $\mathrm{w}$ pożądanej reputacji. Doskonała reputacja jest $\mathrm{w}$ istocie nadrzędnym celem komunikacji korporacyjnej, ze względu na to, iż pozwala stworzyć korzystny klimat dla działalności biznesowej. Korporacyjny ,adaptacyjny potencjał retoryczny” obejmuje szeroki zakres uczciwych i nieuczciwych strategii komunikacyjnych, szczególnie często stosowanych w reklamie i dyskursie PR i zaznaczających za pomocą różnych mediów swoją silną obecność w przestrzeni publicznej. Sam wizerunek korporacji rzadko można uznać za jednorodny - przedsiębiorstwo jako nadawca komunikatu koncentruje się z reguły na określonych elementach tożsamości w celu wywołania pożądanego wizerunku u odbiorców. Ten z kolei będzie zawsze rozproszony i fragmentaryczny ze względu na różnorodność samych odbiorców, których postrzeganie uzależnione jest od szeregu czynników, tj. ich własne doświadczenia czy też ekspozycja na określone komunikaty pozostająca poza kontrolą nadawcy. W dobie Internetu i mnogości potencjalnych źródeł informacji wizerunek będzie miał charakter coraz bardziej dynamiczny i zmienny czy wręcz iluzoryczny.

\section{Tożsamość i wizerunek w ujęciu postmodernistycznym}

Granice pomiędzy tożsamością a wizerunkiem zacierają się szczególnie w perspektywie postmodernistycznej. Zdaniem postmodernistów tożsamość przedsiębiorstwa ulega dezintegracji, ponieważ tożsamość jako taka nie posiada wyraźnie zarysowanego stałego własnego trzonu i staje się odbiciem tymczasowych wizerunków (Gioia et al., 2000: 72). Sam wizerunek wysuwa się we współczesnych organizacjach na pierwszy plan (Baudrillard, 1988b; 1990). Jak zauważają Gioa et al. (2004: 362), bez względu na punkt wyjścia wszystkie aspekty tożsamości przeistaczają się w wizerunek czy wręcz iluzję. Wcześniej tożsamość postrzegana była jako stosunkowo stabilna i odporna na upływ czasu i zachodzące wokół zmiany. Postmoderniści przedefiniowali relację pomiędzy tożsamością a wizerunkiem, dając pierwszeństwo temu ostatniemu i postulując, iż tożsamość niczym kameleon imituje rozmaite wizerunki obecne w przestrzeni publicznej (ibidem: 363). Tożsamość jest zatem przedstawiana jako zjawisko dynamiczne, ulotne i niestabilne, zmieniające się 
w kopię różnorodnych wizerunków organizacji nazwanych simulacra (Baudrillard, 1988a) lub „wizerunkiem bez tożsamości” (Perniola, 1982: 59). Obydwaj badacze podkreślają rolę mediów i specjalistów od komunikacji zawodowej w konstruowaniu i rozpowszechnianiu tych wizerunków.

Baudrillard (1988b) przyjmuje postawę radykalną i podkreśla, iż proces transformacji tożsamości przebiega $\mathrm{w}$ następującej sekwencji: początkowego stadium odbicia rzeczywistości, zniekształcenia jej, ukrycia jej nieobecności, aż do zupełnego oderwania od rzeczywistości. Zmiany te uwypuklają dynamikę wizerunku oraz jego oddalanie się od rzeczywistości. W rezultacie zarówno tożsamość jak i wizerunek stają się iluzją. Takie podejście neguje wizję tożsamości jako zjawiska trwałego i stałego. Jak podkreślają postmoderniści, o tożsamości przedsiębiorstwa możemy mówić jedynie na początku jego istnienia lecz z upływem czasu tożsamość zmienia się w wizerunek, który staje się iluzoryczny.

Gioia et al. (2004: 364) uznają jednak całkowite przekształcenie tożsamości w wizerunek za mało prawdopodobne, wskazując na zewnętrzną i wewnętrzną inercję, która ogranicza podejmowany przez organizację wysiłek mający na celu dostosowanie się do zmian w otoczeniu. Ponadto badacze podkreślają, że pewne elementy tożsamości i wizerunku pozostają odrębne. Rozbudowane organizacje mogą mieć różnorodne tożsamości dostosowane do potrzeb różnych kontekstów i odbiorców (np. pracowników, klientów, konkurencji, itp.). Mnogość rozmaitych aspektów tożsamości uniemożliwia postrzeganie jej jako jednorodnego, statycznego konstruktu i pozycjonuje ją jako zjawisko dynamiczne i stosunkowo nietrwałe (ibidem). Biorąc pod uwagę argumenty postmodernistów postulujące progresywne przekształcanie się tożsamości w wizerunek lub wręcz iluzję oraz argumenty wskazujące na pewne ograniczenia takiej transformacji, można wnioskować, iż wizerunek bez wątpienia wywiera wpływ na tożsamość organizacyjną, ale niekoniecznie tożsamość się w niego przekształca. Podkreślić jednak należy, że obydwa konstrukty są dynamiczne i niestabilne. Niestabilność ta pełni jednak istotną funkcję w życiu organizacji: ułatwia proces adaptacji w zewnętrznym i wewnętrznym otoczeniu (cf. Gioa et al., 2004: 365).

W literaturze poświęconej studiom organizacyjnym perspektywa postmodernistyczna jest marginalizowana i postrzegana jako niestandardowa (np. Jablin i Putnam, 2001; He i Brown, 2013), podobnie zresztą jak podejścia dyskursywne i narracyjne postrzegające tożsamość organizacji jako teksty ustanowione przez dyskurs (np. Brown i Humphreys, 2006; Chreim, 2005; Czarniawska-Joerges, 1994; Humphreys i Brown, 2002; He i Brown, 2013: 10). Według Czarniawskiej-Joerges (1994: 198) „tożsamość organizacji jest konstruowana poprzez ciągły proces narracji, w którym zarówno narrator, jak i odbiorcy formułują, redagują, zatwierdzają lub odrzucają różne elementy tworzonej na bieżąco narracji”. W podobny sposób definiuje tożsamość organizacyjną Brown i Humphreys (2006), przedstawiając ją jako zbiór narracji istotnych dla tożsamości, tworzonych przez uczestników rozmów oraz autorów pisemnych historii, dokumentów, raportów, komunikatów w Inter- 
necie, których celem jest zwrócenie uwagi na zagadnienia związane z władzą, refleksyjnością, wielogłosowością, czasowością i fikcyjnością (Brown, Humphreys i Gurney, 2005).

\section{Ujęcie komunikologiczne}

Z kolei Wood (2004) postrzega pojęcia tożsamości i wizerunku jak dwa przeciwstawne elementy procesu komunikacji. Tożsamość przedsiębiorstwa jest zatem rozumiana jako komunikat o charakterze autoprezentacji przekazywany przez nadawcę w sposób zamierzony bądź niezamierzony poprzez różne kanały komunikacji. Wizerunek przedsiębiorstwa to innymi słowy odbiór tego komunikatu przez jego adresatów, interpretujących go w szerszym kontekście i odniesieniu do szerszych ram referencyjnych (Wood, 2004: 96). Innymi słowy, przedsiębiorstwa nie są jedynymi architektami własnego wizerunku, ponieważ kontekst jego odbioru, interpretacji i zrozumienia jest poza ich kontrolą. Przyznać jednak należy, że przejrzyście skonstruowany i prawidłowo zarządzany wizerunek przekłada się na pozytywny odbiór organizacji, podczas gdy nieudolne kontrolowanie przekazu prowadzić może do zaburzonego wizerunku (Ind, 1990: 21). Z tego względu kluczową rolą tożsamości przedsiębiorstwa jest określenie odpowiedniego wizerunku i przekazanie go w prawidłowy sposób, aby uniknąć jakiegokolwiek rozdźwięku pomiędzy projekcją a interpretacją danego przekazu.

W tym kontekście pojęcie reputacji może pozornie wydawać się terminem zbędnym ze względu na pokrywający się z wizerunkiem zakres semantyczny. Podobieństwo to wynika z usytuowania obydwu tych pojęć po stronie odbiorcy a nie nadawcy. Różnicuje je z kolei ulotny, tymczasowy charakter wizerunku, będącego raczej pewną impresją, i bardziej stały i stabilny charakter reputacji rozumianej jako pewnego rodzaju ocenę dokonaną na podstawie przeszłych i przyszłych działań przedsiębiorstwa. Jak ujmuje to Caroll (2013: 4), reputację przedsiębiorstwa można rozumieć jako często powtarzaną informację o charakterze przedsiębiorstwa charakteryzującą się niską zmiennością. Ponadto Wood and Somerville (2016) podkreślają ewaluacyjny charakter reputacji i jej wymiar historyczny. Ujęcie to wydaje się bardzo przejrzyste i ułatwia wyodrębnienie zakresów znaczeniowych poszczególnych terminów. Z tego względu przyjęte zostanie jako rama referencyjna dla poniżej omówionej analizy.

\section{Studium przypadku: Monsanto}

Różnice pomiędzy tożsamością, wizerunkiem a reputacją zostaną omówione na przykładzie firmy Monsanto - jednej z największych i jednocześnie najbardziej kontrowersyjnych korporacji na świecie zajmującej się rolnictwem i biotechnologią. 
Analizie zostanie poddana zawartość strony internetowej Monsanto (oryginalna strona amerykańska oraz strona polskiego oddziału korporacji) jak również korpus 25 źródeł internetowych obejmujący w przeważającej części elektroniczne artykuły prasowe oraz wpisy na portalu Twitter, blogach i hasła w Wikipedii dotyczące postrzegania firmy. Korporacja ta „,iesząca” się wyjątkowo złą reputacją na całym świecie została wybrana umyślnie, jako tzw. przypadek skrajny, w celu zilustrowania szczególnie dużej rozbieżności pomiędzy jej deklarowaną tożsamością a wizerunkiem i reputacją.

\subsection{Tożsamość firmy}

Głównym nośnikiem tożsamości korporacyjnej jest misja przedsiębiorstwa obecnie najczęściej publikowana na stronie internetowej w sekcji „O nas” lub „Kim jesteśmy”, która z reguły zawiera informacje dotyczące historii, firmy, jej pracowników, zarządu, wyznawanego systemu wartości oraz przedstawia raport korporacyjnej społecznej odpowiedzialności (Corporate Social Responsibility Report), kod etyczny, najważniejsze osiągnięcia, przyznane nagrody, itd.

Monsanto.com określa siebie jako firmę zajmującą się zrównoważonym rolnictwem i wspomagającą rolników w uzyskaniu jak najlepszych zbiorów przy jak najmniejszej eksploatacji naturalnych zasobów takich jak woda czy energia:

Monsanto is a sustainable agriculture company. We deliver agricultural products that support farmers all around the world. (ŹI 1).

Sporo uwagi poświęcone zostało systemowi wartości firmy, który ma gwarantować uczciwość i etyczne zachowania na wszystkich poziomach działalności firmy i we wszystkich relacjach z otoczeniem wewnętrznym i zewnętrznym firmy. Duży nacisk położony jest na deklarowane wsparcie dla rolników i ich rodzin oraz społeczności lokalnych. Lektura zamieszczonych na stronie internetowej informacji pozwala na sformułowanie wniosku, że firma zajmuje się przede wszystkim zrównoważonym rolnictwem, działalnością społeczną i ekologiczną. W tekście zauważalna jest wysoka częstotliwość słowa „zrównoważony”, stosowanego w różnych kontekstach i w odniesieniu do niemalże wszystkich aspektów działalności firmy. Uwagę przykuwa również użycie słowa „holistycznie” we fragmencie poniżej:

We work to help farmers produce food in a sustainable way. We think holistically about how our food is grown so farmers have the tools they need to have better harvests - to make a plate of meats, grains, fruits and vegetables within reach for every family. (ŹI 2)

Wyraźne odniesienia do ekologii są również widoczne w warstwie wizualnej. Liczne zamieszczone na stronie internetowej fotografie przedstawiają sielankowe obrazy nieskażonej natury i roślin, co silnie odbiega od rzeczywistej działalności 
firmy. Na pierwszy rzut oka trudno jednak się zorientować, czym w istocie zajmuje się firma. Nie wspomina się bowiem faktu, iż Monsanto to lider rolnictwa wielkoformatowego, bardzo niekorzystnego z punktu widzenia ekologii, oraz producent wysoce toksycznych środków ochrony roślin, zaangażowany w sprzedaż nasion i ich genetyczną modyfikację. Liczne odwołania do ekologii można zatem uznać za tzw. „ekościemę” (ang. greenwashing).

Więcej konkretnych informacji dotyczących działalności firmy można znaleźć na jej polskiej stronie, które jest bardziej oszczędna i skromna pod względem formy i treści od swojego amerykańskiego pierwowzoru.

Monsanto jest firmą ukierunkowaną na rozwój rolnictwa oraz wspieranie rolników na całym świecie w dostarczaniu wysokiej jakości surowców do produkcji pasz, żywności, odzieży oraz biopaliw.

Monsanto Polska Sp. z o. o. to lokalny oddział amerykańskiego lidera w dziedzinie nowoczesnego rolnictwa i biotechnologii. Czerpiąc z ponad 100-letniego doświadczenia firmy obecnej na kontynentach całego świata, z powodzeniem funkcjonuje na polskim rynku od 1995 roku. Od lat siedemdziesiątych firma działała w Polsce w ramach Monsanto Company.

Monsanto Polska to producent najskuteczniejszych środków ochrony roślin oraz hodowca nasion rzepaku ozimego i dostawca nasion rzepaku ozimego i kukurydzy wspierających rolnictwo gospodarstw wielkoobszarowych oraz rodzinnych. (ŹI 3)

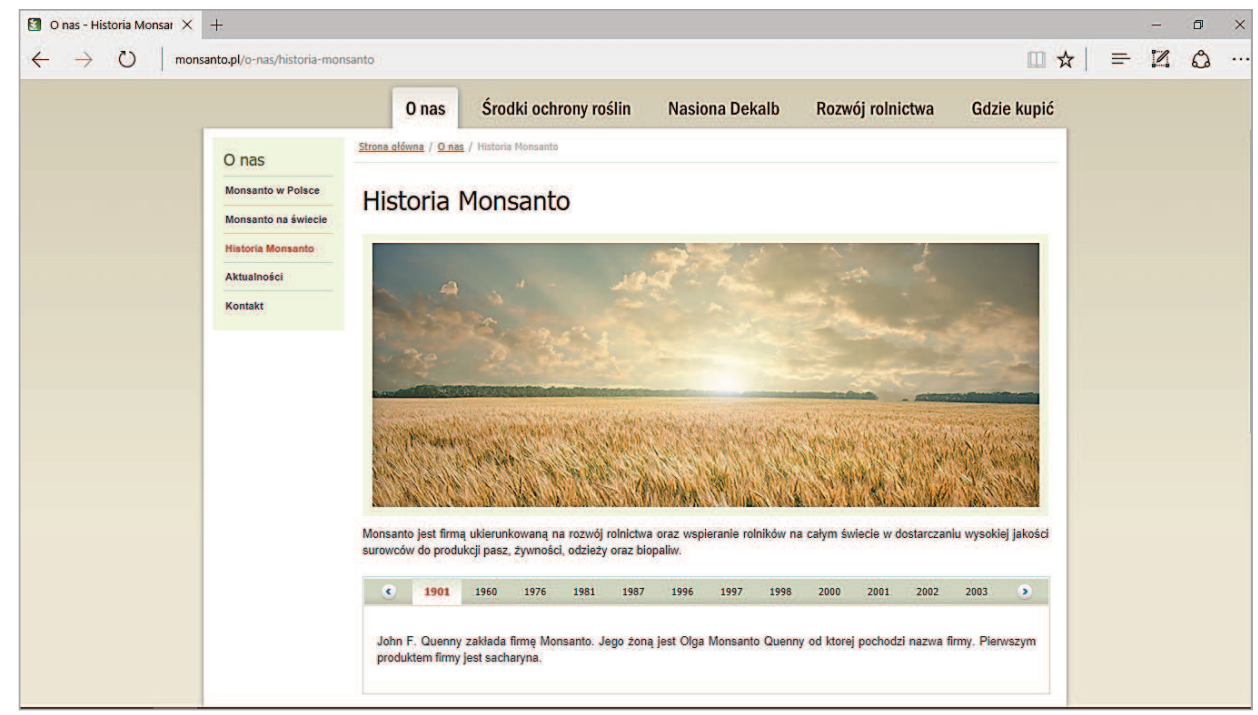

Ilustracja 1. Historia Monsanto (zrzut ekranu) 
W sekcji dotyczącej historii firmy pojawiają się ogólnikowe informacje dotyczące roku jej założenia i kluczowych z punktu widzenia korporacji wydarzeń, dotyczących otwarcia kolejnych oddziałów firmy, wprowadzanych na rynek produktów, itp.; przekaz ten jest jednoznacznie pozytywny (patrz Ilustr. 1). Firma kreuje się na żywiciela ludzkości, konsekwentnie pomijając jednak informacje dotyczące jej zaangażowania w produkcję żywności genetycznie modyfikowanej oraz toksycznych środków chwasto- i owadobójczych.

Monsanto to globalny lider rynkowy branży rolniczej, specjalizujący się w takich obszarach jak biotechnologia, hodowla odmian roślin uprawnych (rolniczych i ogrodniczych) oraz środków ochrony roślin.

\section{Potencjał}

Firma powstała w 1901 roku w St. Louis w Stanach Zjednoczonych. Obecnie, Monsanto zatrudnia w swoich ponad 380 oddziałach rozlokowanych na całym świecie ponad 17000 pracowników. Monsanto jest jednym z największych na świecie dostawców nowoczesnych i sprawdzonych rozwiązań biotechnologicznych w rolnictwie. (ŹI 4)

\subsection{Wizerunek i reputacja}

Nieco inny obraz korporacji wyłania się po opuszczeniu strony internetowej firmy i wpisaniu w wyszukiwarkę hasła „Monsanto”. Nazwa firmy natychmiast pojawia się w kontekście żywności genetycznie modyfikowanej, określanej w prasie anglojęzycznej mianem „monster food”, „Frankenstein food” czy też ,frankenfood”, co budzi natychmiast wysoce negatywne skojarzenia. W polskiej strefie internetowej pojawia się z kolei określenie ,żywność masowego rażenia” (ŹI 6) w odniesieniu do żywności produkowanej przez Monsanto. Wymowny jest również tytuł artykułu o żywności produkowanej przez Monsanto, który ukazał się w polskiej edycji Newsweeka (31.07.2013 ŹI 7): „Kolacja z Frankensteinem” i bardzo podobny 17 lat temu w tygodniku Wprost (05.09.1999; ŹI 8). Sama firma przedstawiana jest z kolei jako „sekta biznesowo-lucyferyczna” (ŹI 9). Diaboliczne skojarzenia można również odnaleźć w terminie „Monsatan” ukutym przez aktywistów ekologicznych, z własnym hashtagiem na portalu Twitter: \#monsatan (ŹI 10).

Sprzeciw wobec działalności Monsanto przybiera często bardzo kreatywne formy. Dla przykładu, na blogu „Monsanto memes” znaleźć można liczne memy i materiały graficzne, które w sposób satyryczny przedstawiają koncern Poniżej przykładowy mem (Ilustr. 2).

Na uwagę zasługują również materiały graficzne, które w sposób krytyczny odnoszą się do własnej autonarracji Monsanto, pozycjonującej firmę jako głównego żywiciela ludzkości. Sielankowy krajobraz rolniczy został zestawiony z grafiką często umieszczaną na toksycznych produktach stanowiących zagrożenia dla życia (Ilustr. 3). 


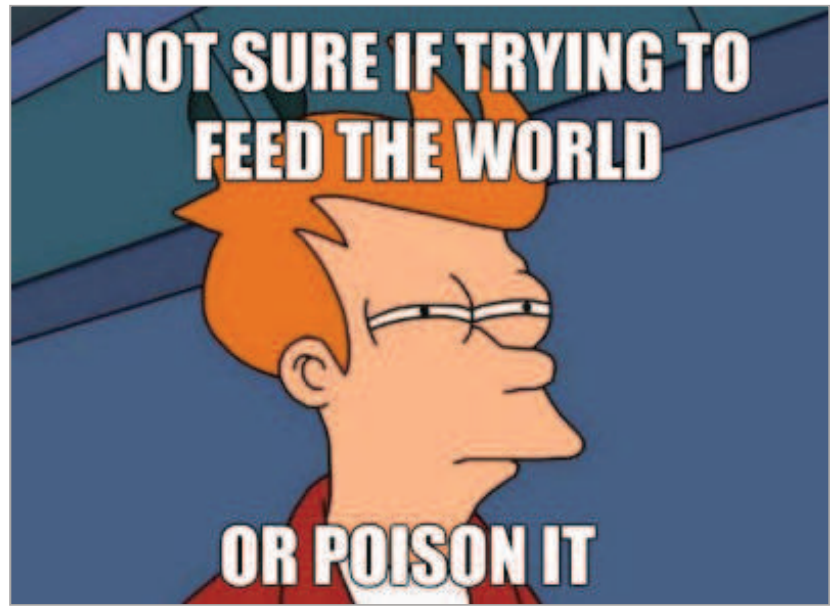

Ilustracja 2. Mem 1

Źródło: (ŹI 12)

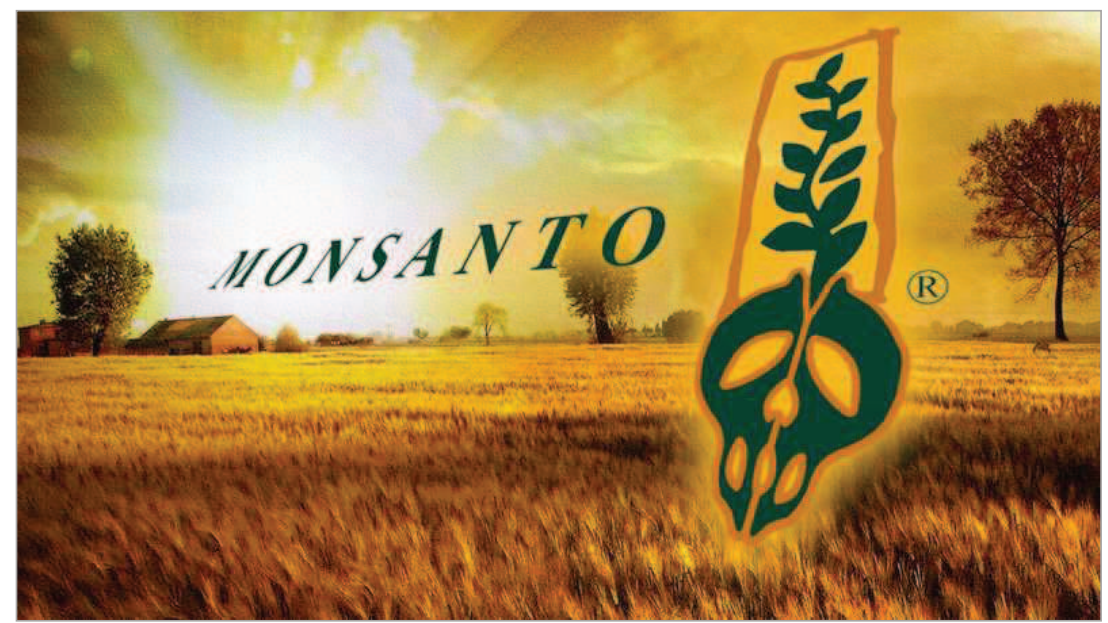

Ilustracja 2. Mem 2

Źródło: (ŹI 13)

\section{Reputacja}

Skrajne rozbieżności pomiędzy kreowaną przez Monsanto tożsamością a jej wizerunkiem i stały negatywny przekaz dotyczący działalności firmy w istotny sposób wpłynęły na reputację firmy, która jest zdecydowanie negatywna. We wpisie poświęconym Monsato w Wikipedii uwypuklona została informacja, iż: 
Monsanto stało się w istocie jednym z najbardziej znienawidzonych przez działaczy ruchów antyglobalistycznych i ekologicznych koncernów międzynarodowych. Wiele innych korporacji chemicznych i biochemicznych jest również stale narażonych na tego rodzaju ataki, jednakże Monsanto jest wyjątkowo popularnym celem ataku aktywistów pro-ekologicznych. (ŹI 14)

W istocie Monsanto pozostaje jednym z liderów rankingów najbardziej znienawidzonych firm na świecie:

- The 15 most hated brands in the world 04.06.15 (ŹI 15);

- America's most loved and hated companies 05.02.2015 (ŹI 16);

- Natural Society Poll 11.11.2014 (ŹI 17);

- Nielsen's report on the companies with the best (and worst) reputations 12.05.2016 (ŹI 18).

Zła reputacja wiąże się z negatywnym postrzeganiem firmy na całym świecie, co z kolei prowadzi nie tylko do oporu społecznego i braku akceptacji prowadzonej przez firmę działalności, lecz równie niesie ze sobą skutki finansowe.

Poważne problemy $\mathrm{z}$ reputacją Monsanto są również widoczne w Europie. $\mathrm{W}$ prasie zachodnioeuropejskiej szeroko komentowano fuzję Monsanto z niemieckim koncernem Bayern. Dla przykładu, sprawie tej poświecono obszerny artykuł w brytyjskim The Telegraph (ŹI 19), przypominając przy okazji niebyt chwalebną 115-letnią historię Monsanto naznaczoną takimi „osiągnięciami” jak stworzenie bomby atomowej, produkcję zabójczego dla środowiska DDT i środka roślinobójczego Agent Orange stosowanego przez armię amerykańską podczas wojny w Wietnamie, co doprowadziło do katastrofy ekologicznej w tym kraju i spowodowało liczne wady wrodzone u dzieci. Nietrudno zauważyć, iż autonarracja historyczna Monstanto nie uwzględnia tych wydarzeń, wypierając je z własnej tożsamości.

Fala oburzenia na mariaż firmy Bayer $^{1}$ - wynalazcy aspiryny i jednej z najbardziej szanowanych firm - odbiła się szczególnie szerokim echem w Niemczech. Wypominano przede wszystkim społeczne skutki działalności Monsanto. Uwypuklone zostało bezlitosne traktowanie rolników przez Monsanto, zmuszanych do kupowania i stosowania wyłącznie nasion opatentowanych i produkowanych przez firmę, co skutkowało przejęciem pełnej kontroli nad życiem rolników i ich całkowitym uzależnieniem od firmy. Z kolei rolnicy odmawiający współpracy z Monsanto w wielu miejscach na świecie narażeni byli na kosztowne procesy sądowe, utratę majątku czy wręcz zostali doprowadzeni do samobójstwa. Sprawa ta jest szeroko komentowana $\mathrm{w}$ mediach i podejmowana przez najpoważniejsze tytuły prasowe:

\footnotetext{
${ }^{1}$ Na marginesie w Polsce reputacja koncernu Bayer nie jest już tak jednoznacznie pozytywna. Po wpisaniu do wyszukiwarki hasła „Bayer historia” pojawiają się liczne artykuły i wpisy dotyczące niechlubnej historii koncernu, który w czasie II wojny światowej był częścią koncernu I.G. Farben produkującego m.in. Cyklon B. (ŹI 26). Zagadnienie to porusza również Jeffreys (2004) w książce Aspirin: The remarkable story of a wonder drug.
} 
(ŹI 20; 21; 22; 23; 24; 25). W swoim artykułach poświęconych tej kwestii dr Vandana Shiva, światowej sławy akademiczka, aktywistka ekologiczna i ekofeministka używa wręcz metafory „nasiona samobójstwa” (ŹI 27; 28). W mediach wiele uwagi poświęca się również zbiorowym pozwom rolników przeciw firmie Monsanto (ŹI 29).

Opór społeczny wobec działalności Monsanto jest widoczny nie tylko w mediach lecz przybiera formę aktywnego protestu obywatelskiego. Organizacje ekologiczne nawołują do bojkotu firmy i organizują liczne akcje protestacyjne. Przykładowo, ostatnia $\mathrm{z}$ takich akcji regularnie przeprowadzonych na szeroką skalę miała miejsce 16 października 2016 - w światowy dzień żywności, podczas którego tysiące ludzi na całym świecie wzięło udział $\mathrm{w}$ marszu protestacyjnym przeciw Monsanto (march-against-monsanto.com) pod hasłem „Czas odzyskać naszą planetę" (ŹI 30).

\section{Wnioski}

Celem powyższej analizy było pokazanie rozbieżności pomiędzy kreowanym przez firmę Monsanto wizerunkiem a rzeczywistą reputacją firmy. Koncern pozycjonuje się jako przyjazny środowisku nowoczesny producent żywności, który odgrywa znaczącą rolę w rozwiązywaniu problemu głodu na świecie. Działalność firmy określana jest jako „zrównoważona” i „odpowiedzialna społecznie”. Zupełnie inny obraz korporacji wyłania się z choćby pobieżnej analizy materiałów dostępnych w sieci, których wydźwięk jest zdecydowanie pejoratywny. Materiały te, tworzone zarówno przez profesjonalnych dziennikarzy współpracujących z wiodącymi tytułami prasowymi, jak również aktywistów ekologicznych i amatorów, przedstawiają działalność firmy jako skrajnie szkodliwą dla planety i zrównoważonego rozwoju. Kontrast pomiędzy autonarracją Monsanto a jej interpretacją przez odbiorców jest tak silny, że przekaz korporacyjny kojarzy się z nachalną propagandą i wywołuje wręcz efekt satyryczny. Widoczne jest to szczególnie w kreatywnej działalności internautów przejawiającej się w tworzeniu memów i licznych materiałów graficznych świadczących o krytycznej świadomości odbiorców wykazujących się głęboką refleksją. Co prawda informacje dotyczące rzeczywistej działalności Monsanto są stosunkowo łatwe do zdobycia, jednak samo dotarcie do nich wymaga pewnego wysiłku i motywacji. O prawdziwym kryzysie reputacji firmy świadczy nie tylko ostra krytyka werbalna lecz również czynny opór wobec działalności firmy. Negatywnego wizerunku firmy nie lagodzi bardzo pozytywna, proekologiczna autoprezentacja, która traktowana jest raczej jako fasadowa działalność public relations. Komunikat nadawcy charakteryzuje się zatem słabą wiarygodnością, co stanowi dowód na to, iż wizerunek, a długofalowo reputacja, w dużej mierze pozostają poza jego kontrolą. 


\section{Bibliografia}

Balmer, J.M.T. i S.A. Greyser. 2002. „Managing the multiple identities of the organization”. California Management Review 44. 72-86.

Barnett, M.L., Jermier, J.M. i B.A. Lafferty. 2006. „Corporate reputation: the definitional landscape”. Corporate Reputation Review 9.1. 26-38.

Baudrillard, J. 1988a. The ecstasy of communication (tłum. B. Schutze, i C. Schutze). New York: Semiotext(e).

Baudrillard, J. 1988b. „Simulacra and simulations”. W zbiorze: Poster, M. (red.). Jean Baudrillard: selected writings. Stanford, CA Stanford University Press. 166-184.

Baudrillard, J. 1990. Seduction (tłum. B. Singer). New York: Culturtext.

Bhatia, V.K. i J. Lung. 2006. „Corporate identity and generic integrity in business discourse”. W zbiorze: Palmer-Silveira J.C., Ruiz-Farrido, M.F. i I. Fortanet-Gómez (red.). Intercultural and international business communication: theory, research and teaching. Bern: Peter Lang. 265-285.

Brown, A.D. i M. Humphreys. 2006. „Organizational identity and place: a discursive exploration of hegemony and resistance". Journal of Management Studies 43. 231-257.

Brown, A.D., Humphreys, M. i P.M. Gurney. 2005. „Narrative, identity, and change: a case study of Laskarina Holidays". Journal of Organisational Change Management 18.4. 312-326.

Brown, T.J., Dacin, P.A., Pratt, M.G. i D.A. Whetten. 2006. „Identity, intended image, construed image, and reputation: an interdisciplinary framework and suggested terminology". Journal of Academy of Marketing Science 34.2. 99-106.

Chreim, S. 2005. „The continuity-change duality in narrative texts of organizational identity”. Journal of Management Studies 42. 567-593.

Cornelissen, J.P., Haslam, S.A. i J.M.T. Balmer. 2007. „Social identity, organizational identity and corporate identity: towards an integrated understanding of processes, patternings and products". British Journal of Management 18. S1-S16.

Czarniawska-Joerges, B. 1994. „Narratives of individual and organizational identities”. W zbiorze: Deetz, S. (red.). Communication yearbook. Newbury Park, CA: Sage. 193-221.

Fombrun, C. i V. Rindova. 2000. „The road to transparency: reputation management at Royal Dutch/Shell”. W zbiorze: Schultz, M. i M.J. Hatch (red.). The expressive organization. Oxford: Oxford University Press.77-96.

Gilpin, D. 2010. „Organizational image construction in a fragmented online media environment”. Journal of Public Relations Research 22.3. 265-287.

Gioia, D.A., Schultz, M. i K.G. Corley. 2000. „Organisational identity, image, and adaptive instability”. Academy of Management Review 25. 63-81.

Gioia, D.A., Schultz, M. i K.G. Corley. 2004. „Organizational identity, image, and adaptive instability”. W zbiorze: Hatch, M.J. i M. Schultz (red.). Organizational identity: a reader. Oxford: Oxford University Press. 349-376.

Gotsi, M. i A.M. Wilson. 2001. „Corporate reputation: seeking a definition”. Corporate Communications: An International Journal 6.1. 24-30.

Hatch, M.J. i M. Schultz. 2000. „Scaling the tower of Babel: relational differences between identity, image and culture in organizations". W zbiorze: Schultz, M., Hatch, M.J. i M.H. Larsen (red.). The expressive organization. Linking identity, reputations, and corporate brand. Oxford: Oxford University Press. 11-35.

Hatch, M.J. i M. Schultz. 2001. „Are the strategic stars aligned for your corporate brand?” Harvard Business Review 79.2. 128-135.

He, H. i A.D. Brown 2013. „Organizational identity and organizational identification: a review of the literature and suggestions for future research". Group and Organization Management 38.1. 3-35. 
Humphreys, M. i A.D. Brown. 2002. „Narratives of organizational identity and identification: a case study of hegemony and resistance". Organization Studies 23. 421-447.

Ind, N. 1990. The corporate image. London: Kogan Page.

Jablin, F.M. i L.L. Putnam (red.). 2001. Organizational communication: advances in theory, research and methods. Thousand Oaks: Sage Publications, Inc.

Jeffreys, D. 2004. Aspirin: the remarkable story of a wonder drug. London: Bloomsbury Publishing.

Kenny, K., Whittle, A. i H. Willmort. 2011. Understanding identity and organizations. London: Sage Publications Ltd.

Melewar, T.C. 2003. „Determinants of the corporate identity construct: a review of the literature”. Journal of Marketing Communications 9. 195-220.

Perniola, M. 1982. Dazzling images. Aarhus: Sjakalen.

Puppel, S. 2015. „Język w podmuchu, posiewie i przepływie: uwagi w sprawie synergii porządków komunikacyjnych w kontekście ekoglottodydaktyki”. W zbiorze: Puppel, S. (red.). MOTEK. Motywy ekolingwistyczne: w stronę ekoglottodydaktyki. Poznań: Katedra Ekokomunikacji UAM. 143-150.

Puppel, S. 2016. „Kuźnia Hefajstosa czyli krótki zarys teorii wizerunku w komunikacji ludzkiej”. Scripta Neophilologica Posnaniensia XVI. 109-124.

Simoes, C., Dibb, S. i R.P. Fisk. 2005. „Managing corporate identity: an internal perspective”. Journal of the Academy of Marketing Science 33. 153-168.

Wood, E. 2004. „Corporate identity”. W zbiorze: Theaker, A. (red.). The public relations handbook. London/New York: Routledge. 95-114.

Wood, E. i I. Somerville. 2016. „Public relations and corporate identity”. W zbiorze: Theaker, A. (red.). The public relations handbook. London/New York: Routledge. 144-171.

\section{Źródła internetowe (prymarne)}

ŹI1: http://www.monsanto.com/whoweare/pages/default.aspx [dostęp 16.10.2016].

ŹI2: http://discover.monsanto.com/discover-us/ [dostęp 16.10.2016].

ŹI3: http://www.monsanto.pl/o-nas/monsanto-w-polsce [dostęp 16.10.2016].

ŹI4: http://www.monsanto.pl/o-nas/monsanto-na-swiecie [dostęp 16.10.2016].

ŹI5: http://www.monsanto.pl/o-nas/historia-monsanto [dostęp 16.10.2016].

ŹI6: http//www.maya.net.pl/opinie.php?LANG=pl\&sub=listy\&id=369 [dostęp 16.10.2016].

ŹI7: http://www.newsweek.pl/polska/w-najnowszym-newsweeku--kolacja-z-frankensteinem,107005,1,1.html [dostęp 16.10.2016].

ŹI8: https://www.wprost.pl/tygodnik/5459/Kolacja-Frankensteina.html [dostęp 16.10.2016].

ŹI9: http://www.himavanti.org/pl/c/artykularnia/monsanto-i-inne-koncerny-gmo-jako-lucyferyczne-sektybiznesowe) [dostęp 16.10.2016].

ŹI10: https://twitter: \#monsatan [dostęp 16.10.2016].

ŹI11: https://twitter.com/search?q=\%23monsantoevil\&src=typd [dostęp 16.10.2016].

ŹI12: http://monsantomemes.tumblr.com/ [dostęp 16.10.2016].

ŹI13: http://www.activistpost.com/2016/05/group-of-farmers-files-lawsuit-against-monsanto-claimingroundup-gave-them-all-cancer.html [dostęp 16.10.2016].

ŹI14: https://pl.wikipedia.org/wiki/Monsanto [dostęp 16.10.2016].

ŹI15: http://www.therichest.com/rich-list/poorest-list/the-15-most-hated-brands-in-the-world/ [dostęp 16.10.2016].

ŹI16: http://www.bloomberg.com/news/articles/2015-02-05/america-s-most-loved-and-most-hated-com panies [dostęp 16.10.2016].

ŹI17: http://naturalsociety.com/monsanto-3rd-hated-company-abroad-right-behind-bp/ [dostęp 16.10.2016]. 
ŹI18: http://247wallst.com/special-report/2016/05/12/companies-with-the-best-and-worst-reputations-4/6/ [dostęp 16.10.2016].

ŹI19: http://www.telegraph.co.uk/business/2016/05/28/the-frankenstein-merger-how-bayers-bid-for-mon santo-could-create/ [dostęp 16.10.2016].

ŹI20: https://rinf.com/alt-news/breaking-news/the-seeds-of-suicide-how-monsanto-destroys-farming/ [dostęp 16.10.2016].

ŹI21: http://naturalsociety.com/monsantos-gmo-seeds-farmer-suicides-every-30-minutes/ [dostęp 16.10.2016].

ŹI22: http://projectcensored.org/21-monsanto-indias-suicide-economy/ [dostęp 16.10.2016].

Źl23: http://www.commondreams.org/views/2013/03/27/monsanto-and-seeds-suicide [dostęp 16.10.2016].

ŹI24: http://www.globalresearch.ca/the-seeds-of-suicide-how-monsanto-destroys-farming/5329947 [dostęp 16.10.2016].

ŹI25: http://modernfarmer.com/2014/03/monsantos-good-bad-pr-problem/ [dostęp 16.10.2016].

ŹI26: http://biznes.onet.pl/wiadomosci/swiat/heroina-aspiryna-i-cyklon-b-historia-koncernu-bayer/8phb6 [dostęp 16.10.2016].

ŹI27: https://www.theguardian.com/global-development/gallery/2014/may/05/india-cotton-suicides-farmerdeaths-gm-seeds [dostęp 16.10.2016].

ŹI28: http://articles.economictimes.indiatimes.com/2012-08-31/news/33521331_1_agrarian-reasons-bank ruptcy-or-sudden-change-change-in-economic-status [dostęp 16.10.2016].

ŹI29: http://www.stuartwilde.com/2013/02/6-2-billion-law-suit-against-monsanto/ [dostęp 16.10.2016].

ŹI30: http://www.march-against-monsanto.com/the-truth-about-gmo-safety-the-mainstream-media-willnever-tell-you-about/ [dostęp 16.10.2016]. 